\title{
ACTION PLEASE
}

\author{
By G. R. LANE
}

T $F$ arguments as to how Canada is to get succeeding crops of timber were getting us any place, it would be worth the talk. But we are getting nowhere. What we demand is ACTION. Most of us agree that all land unfit for agriculture and within reasonable distances of markets should be producing something. God never intended it to stand idle. Foresters know how to take such land and change it from growing weed trees to growing a valuable crop.

There are unmistakable signs that the pressure of public opinion is going to require some action by the bodies that are answerable to the people for the public forests. The manner in which the forests will be best handled may safely be left to the foresters themselves. By technical training and experience they know what should be done and how it can be done most economically. They have access to all previous experiments carried out by other foresters, and have the technical training to properly interpret those results and apply them to new conditions.

In too many cases the forestry policy of governments and corporations have been formed by those who knew very little about the woods. The policy was set to suit the current financial statement rather than the future generation. In too many cases the carrying out of that policy has been assigned to those with ability to cut down the forests, but with no training as to how to build them up. Even to-day some amazing appointments are being made by those responsible for the administration of the forest and the harvesting of its products.

The same conscientious care should be taken in choosing forest admin, istrators as a factory manager would take in choosing his department heads. He doesn't bring in an aviator and make him head of the department manu. facturing engine parts. Being a newspaper reporter does not qualify one for being superintendent of a game sanctuary or a national park. Being a club supporter does not necessarily qualify one to direct an extensive reforestation frogramme.

The argument that it costs too much money to insure a second timber crop is no excuse for not doing something about it. Of course it costs money and labour. Any farmer or gardener knows that before another crop can be grown new seed must reach the ground or no plant is produced, fertilizer must be added or the soil soon becomes too poor to support growth, the weeds must be killed or the crop will be choked and the nutrients robbed 
from the soil. If nothing is done the land becomes a useless deserted place.

Knowing this, a farmer figures on retaining so much from the selling price of his last crop to put his land in shape, sow his seed, and eradicate the weeds until another crop is harvested. This is sound business practice.

It should be somewhat similar with a forest. The crop must be protected from fire. Disease must not be allowed to run unchecked. The cut should be made when the crop is mature and must be made in such a way that a better future crop will result. The new crop must be given some chance to reach maturity. Doesn't that sound like common sense?

But we must do more than this. We must do something to rectify the forestry malpractices of former generations. We must not and cannot be satisfied with the condition of our forests as they are to-day.

Think what it must cost companies to harvest a crop where the average run is less than ten cords of merchantable wood per acre. A forest engineer must make roads and stream improvements, build small scattered camps, and cut about twenty-four square miles of such timber every year just to keep an average sized pulp mill running steadily. This condition is not uncommon.

Nearly every forestry, and fish and game organization has begged the government to use some of the direct relief money on some simple forestry frojects that will take more of the people away from the cities, give them work to do, and have something afterwards to show for the money. We know that cabinet ministers are sacrificing their health in the interests of the unemployed, but just the same, when the next national calamity comes along, with an acute demand for forest products, there will be much criticism levelled at this generation of voters for not having some good accessible forests to show for the vast national debt.

We know that a certain amount of public money will be and must be spent for the protection and perpetuation of the raw material of the country's second largest industry. When that time comes, our first consideration must be the improvement in the protection of the forests we still have. There has been as marked improvement in the machinery and equipment used for the detection and suppression of forest fires as will be noted in any up-to-date city fire department. This must be kept up to date.

No sudden radical changes in the personnel of any city fire department would be tolerated by the citizens. They would fear for their property. The same should apply to the forests. There is no doubt but that the main factor for the small acreage of forest annually destroyed in the Province of Quebec is mainly due to a continuity of personnel. The government and the companies operating in the province realize that forest fire protection is a 
serious business (1923 taught them that) and changes must be made slowly in order to retain the experienced men.

We are doing everything possible to encourage tourists and our own citizens to take to the woods. It is a healthful, stimulating recreation and it helps to circulate money. But please remember, that the efficiency of the forest protection organizations must increase in direct proportion to the increase in people travelling in the forest.

In farming you may have two types of crops. On such as hay gives a comparatively low yield per acre and does not require much expenditure. On the other hand, there are some truck crops which yield a valuable return per acre but also require a great expenditure of labour and money.

In the forests there are some stands of valuable timber close to transportation channels which should receive much more protection than less valuable stands which are difficult to transport. The former should receive much more consideration than the latter when considering the intensity of protection. This has not always been done because we are prone to criticise on the number of acres burned rather than the value and quality of the timber destroyed.

The United States and Great Britain are showing the world that they intend to rectify the mistakes of former generations by setting a terrific pace in reforestation and in the proper silvicultural treatment of young stands. Previous to the war, it was Germany and France who were leading the world in reforestation. But the British Isles got such a scare when the submarine warfare practically cut her off from importation of lumber, that they decided never to be caught again, and since the war has been planting more trees each year than France and Germany put together, and is still planting annually more than any other country in the world.

If we in Canada are to have something to show for our relief money, it would be well to begin with the land nearest the markets and the transportation routes. The planting of waste and burned areas of crown lands along the provincial and trans-Canada highways would increase the beauty of the provinces. Other countries think of us as a perpetual supply of good timber. It would be too bad to disillusion them by showing only barrens and burns.

Each Province might do more to encourage the farming communities to add to the beauty and wealth of the country by planting more trees. There are very few farms that do not have a few acres of waste land which was only intended by nature to grow trees. Seedlings from government nurseries should be supplied to farmers at cost. Ontario supplies trees to its farmers 
free. Every such tree planted has a potential value which must not be underestimated.

The provincial governments might make it a matter of policy that each fire ranger in every Provincial Forest be required annually to plant one thousand trees along open spaces of the trails of his district, or along open spaces on trout streams, or parallel to roads and trails crossing big burns. Every provincial and federal park ranger should be required each year to plant two thousand trees. What if it is only a drop in the bucket compared with what is being burned each year, it is a drop, and the people would be thankful to see that much.

Politicians and editors should take notice that foresters cannot produce trees on a moment's notice as a conjurer would produce a rabbit from a hat. It takes three years to grow pines and four years to grow spruce to the state where they are large enough and hardy enough to be planted out in the blistering sun of a large burn. That means that this is the summer to collect seed without further delay to meet the agitation for better forestry practice which will be upon us in a year or two.

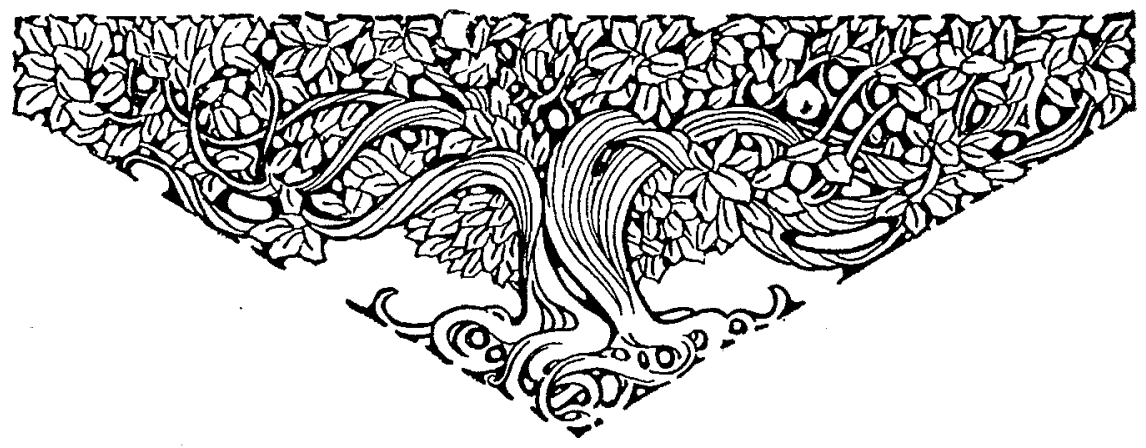

